No. $08-28$

\title{
福祉工学シンポジウム2008 講演論文集
}

Proceedings of the Welfare Engineering Symposium 2008

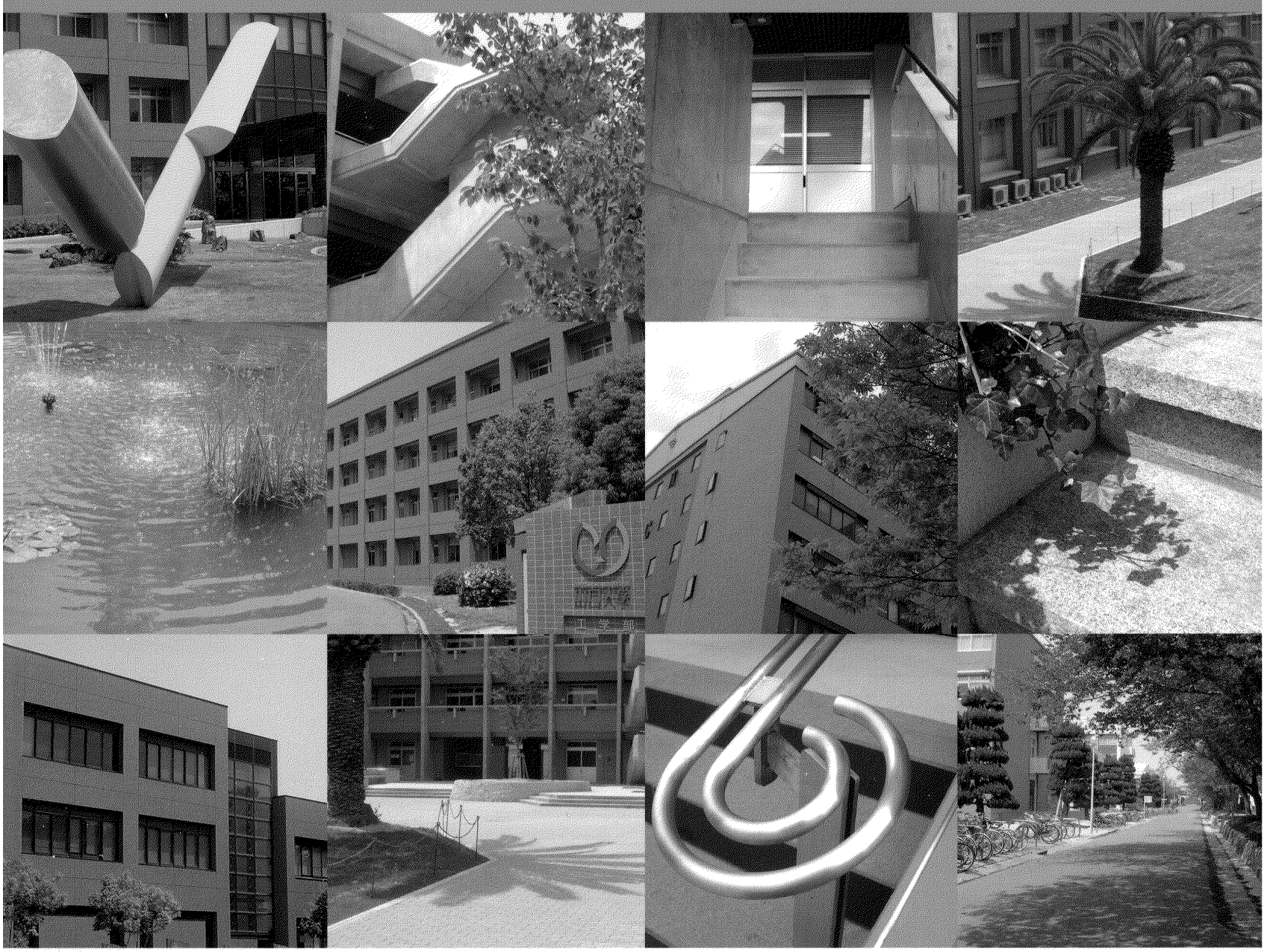

主催 日本機械学会

機素潤滑設計部門(幹事部門) 機械力学·計測制御部門

ロボティクス・メカトロニクス部門 バイオエンジニリアリング部門

共催 山口大学工学部

併催 第6回生活支援工学系学会連合大会

会期 2008年9月17日(水) 19日(金)

会場 山口大学工学部 (山口県宇部市) 